\title{
Perancangan Aplikasi Pencarian Lokasi Penitipan Hewan Peliharaan Menggunakan Metode Haversine Formula (Studi Kasus: Wilayah Jakarta Barat)
}

\author{
Denka Amalia Putri ${ }^{1}$; Ratna Mutu Manikam ${ }^{2}$ \\ ${ }^{1,2}$ Universitas Mercu Buana \\ $141816010042 @$ student.mercubuana.ac.id \\ ${ }^{2}$ ratna_mutumanikam@mercubuana.ac.id
}

\begin{abstract}
Jakarta is the capital of Indonesia, Jakarta is a city that is visited by newcomers from various regions. And has a population that continues to increase every year. the need for information is fundamental to the needs of the community, one that is needed by the community is the need for pet care so that the owner must take the time to take care of their animal care but the animal owner sometimes has a lot of work to be done. This results in pets not being properly maintained. Apart from work, pet owners are forced to travel far away and it is not possible to bring their pets. in the presence of this problem, a website-based application for animal care is made. Where with the application, the animal lovers can easily get information on the location of the nearest pet care. This system uses the haversine formula method to find the nearest location.
\end{abstract}

Keywords: Jakarta, Application, Animal care, Information, location, haversine formula method.

\begin{abstract}
ABSTRAK
Jakarta merupakan ibu kota dari Indonesia, Jakarta merupakan kota yang banyak dikunjungi oleh pendatang baru dari berbagai daerah. Dan memiliki jumlah penduduk yang terus meningkat tiap tahunnya. kebutuhan akan informasi adalah hal mendasar bagi kebutuhan masyarakat, salah satu yang di butuhkan masyarakat adalah kebutuhan akan perawatan hewan peliharaan sehingga pemilik harus meluangkan waktu untuk mengurus hewan pemeliharaan mereka akan tetapi pemilik hewan terkadang memiliki banyak perkerjaan harus diselesaikan. Hal ini menyebabkan hewan peliharaan tidak terawat dengan baik. Selain bekerja pemilik hewan terpaksa harus berpergian jauh dan tidak memungkinkan untuk membawa hewan peliharaan mereka. dengan adanya masalah tersebut, maka dibuat aplikasi berbasis website untuk suatu penitipan hewan pemeliharaan. Dimana dengan adanya aplikasi tersebut, maka para pecinta hewan dengan mudah mendapatkan informasi lokasi penitipan hewan peliharaan terdekat. Sistem ini menggunakan metode haversine formula untuk pencarian lokasi terdekat.
\end{abstract}

Kata kunci: Jakarta, Aplikasi, Penitipan hewan, Informasi, lokasi, metode haversine formula 


\section{PENDAHULUAN}

Tingkat kepedulian manusia terhadap hewan sudah mulai meningkat, hal tersebut dapat dilihat dari semakin banyaknya manusia yang memilih hewan sebagai peliharaan serta teman untuk bermain [1]. Pada saat ini sudah banyak masyarakat kota Jakarta Barat yang memelihara hewan peliharaan terutama anjing dan kucing. Jakarta merupakan kota yang banyak dikunjungi oleh pendatang baru dari berbagai daerah karena Jakarta merupakan Ibu kota dari Indonesia[2]. Seringkali pendatang baru dan masyarakat setempat sendiri belum mengenal letak penitipan hewan peliharaan yang ada disekitar tempat dimana mereka tinggal. Sehingga untuk mempermudah pendatang baru dan masyarakat setempat tersebut dalam mendapatkan informasi mengenai lokasi penitipan hewan peliharaan terdekat[3]. salah satu peta digital yang cukup baik dan akurat serta mendukung pengembangan sistem informasi pencarian lokasi ini adalah Google Maps. Peta digital yang dibuat oleh Google ini didukung oleh banyak browser baik di perangkat komputer maupun mobile. Selain itu, memungkinkan pengguna mengetahui koordinat lokasi. Google Maps berperan dalam memberi koordinat lokasi yang digunakan untuk mengikatkan data spasial ke dalam sistem koordinat dan data global [4]. Google Maps memiliki fitur Google Direction yang dapat menghitung rute terpendek antar lokasi. permukaan bumi secara keseluruhan merupakan permukaan yang melengkung dan sama sekali tidak memungkinkan untuk dapat dibentangkan sehingga menjadi bidang datar sempurna tanpa mengalami perubahan atau kerusakan. Dengan demikian, hasil pemetaan dari permukaan bumi yang luas dan melengkung di atas tidak dapat dipetakan pada bidang datar tanpa mengalami distorsi (perubahan) dari bentuk aslinya [5]. Sedangkan untuk menghitung jarak antar dua titik pada peta banyak metode yang dapat digunakan. Salah satu metode yang akurat dalam menentukan jarak antar dua titik adalah metode Haversine Formula [6].

Dan hal ini dapat diatasi dengan web ini. Sehingga dengan aplikasi ini tempat penitipan hewan dapat menggunakan aplikasi ini sebagai tempat menawarkan jasa pada pemilik hewan. Dan pemilik hewan peliharaan dengan mudah mendapatkan informasi lokasi penitipan hewan terdekat di daerah Jakarta Barat.

Penelitian sebelumnya pernah dilakukan terkait dengan pengembangan aplikasi SIG dalam penelitian ini Hari Singgih Pratikto, Suraya dan Edhy Sutanta(2014) telah melakukan penelitian tentang Sistem pencarian Dan Pemesanan Rumah Kos Menggunakan Sistem Informasi Geografis. Hasil dari penelitian tersebut dapat mengembangkan sistem pencarian dan pemesanan rumah kos menggunakan sistem informasi geografis. Sistem ini mampu menyajikan informasi detail tentang pemesanan kamar kos, ketersediaan kamar kos dan pencarian rumah kos sesuai dengan kriteria pengguna. Sistem dikembangkan dengan memanfaatkan software pendukung Framework Codelgniter dan Google Maps[7].

\section{METODE/PERANCANGAN PENELITIAN}

\subsection{Metode Pengembangan Sistem}

Metode Waterfall Menurut Pressman (2015:42), model waterfall adalah model klasik yang bersifat sistematis, berurutan dalam membangun software. model ini sebenarnya merupakan "Linear Sequential Model". Model ini sering juga disebut "classic life cycle" atau metode waterfall. Model ini termasuk ke dalam model generic pada rekayasa perangkat lunak dan pertama kali diperkenalkan oleh Winston Royce sekitar tahun 1970 sehingga sering dianggap kuno, tetapi merupakan model yang paling banyak dipakai dalam Software Engineering (SE). Model ini melakukan pendekatan secara sistematis dan berurutan. Sering disebut waterfall karena ini dilakukan melalui tahap demi tahap yang harus menunggu selesainya tahap sebelumnya dan berjalan berurutan [8]. 
Fase-fase dalam Waterfall Model menurut referensi Pressman dapat dilihat di Gambar 1 :

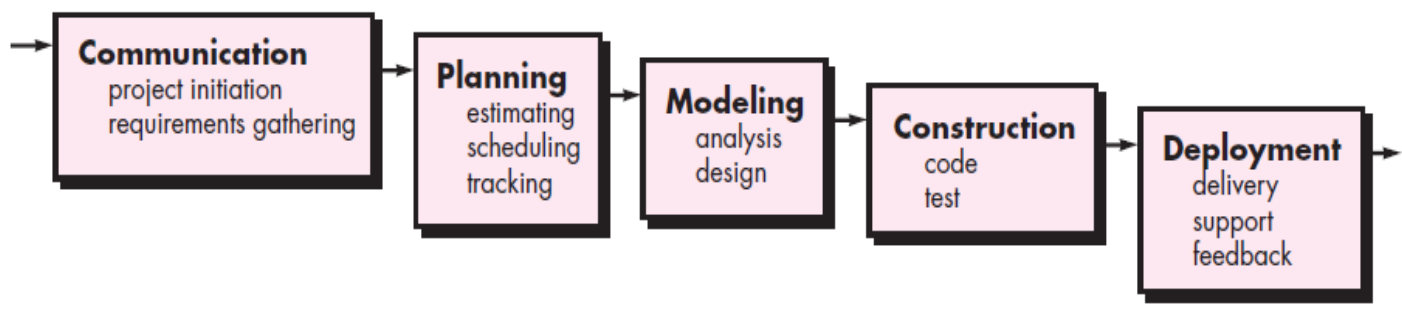

Gambar 1. Waterfall Pressman

Alat bantu dalam perancangan sistem merupakan pemodelan data, mendeskripsikan data yang terlibat dalam perangkat lunak. Adapun alat bantu dalam perancangan sistem berupa ERD, CD, DFD[9].

\subsection{Metode Haversine Formula}

Rumus haversine adalah persamaan yang penting pada navigasi, memberikan jarak lingkaran besar antara dua titik pada permukaan bola (bumi) berdasarkan bujur dan lintang. Penggunaan rumus ini cukup akurat untuk sebagian besar perhitungan, juga memiliki tingkat error yang rendah. Penggunaan algotma ini sudah banyak digunakan antara lain rute angkot terdekat [10], pencarian lokasi tambal ban terdekat [11], dan bahkan pencarian ustadz [12], Haversine formula nantinya akan digunakan dalam perhitungan jarak antara dua titik. Dalam hal ini adalah titik posisi user dan titik posisi tujuan, sehingga dapat menjadi kunci utama dalam perbandingan jarak pada penentuan jarak terdekat.

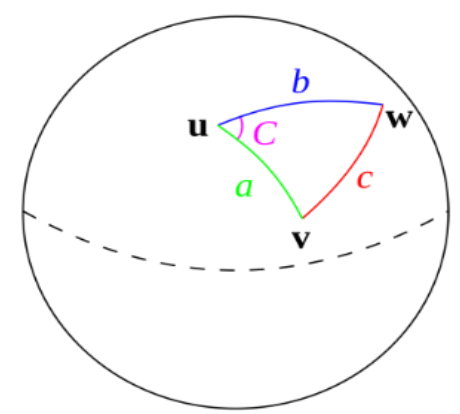

Gambar 2. Ilustrasi Spherical law of cosines

Dari Gambar 2 dapat dihasilkan persamaan persamaan yang digunakan berdasarkan bentuk bumi yang bulat (spherical earth) dengan menghilangkan faktor bahwa bumi itu sedikit elips (elipsodial factor). Ini merupakan kasus khusus dari formula umum dalam trigonometri bola, hukum haversine, yang berkaitan dengan sisi dan sudut segitiga bola. Dalam unit bola, sebuah "segitiga" pada permukaan bola didefinisikan sebagai lingkaran-lingkaran besar yang menghubungkan tiga poin $\mathrm{u}, \mathrm{v}$, dan w pada bola. Jika panjang dari ketiga sisi adalah (dari u ke $\mathrm{v}), \mathrm{b}$ (dari u ke w), dan c (dari v ke w), dan sudut sudut yang berlawanan c adalah C. Maka hukum haversine menjadi sebagai berikut:

$$
\begin{gathered}
\text { Haversine }(c)=\text { haversine }(a-b) \\
\sin (a) \sin (b) \text { haversine }(C)
\end{gathered}
$$


Formula Haversine berfungsi untuk menemukan jarak antara lokasi pengguna dan tujuan lokasi dengan melakukan perhitungan [13]. dengan yang berikut ini :

$$
\begin{aligned}
\Delta \operatorname{long}= & (\text { long } 2+\text { long } 1) \cos (\text { lat } 1+\text { lat } 22)=\cos a \cos b-\sin a \sin b \\
& \Delta \text { lat }=(\text { lat } 2-\text { lat } 1) \\
& \mathrm{a}=\sin 2(\text { lat } 2)+\cos (\text { lat } 1) \cos (\text { lat } 2) \sin 2(\Delta \text { long } 2) \\
& d=\sqrt{ }(a) \mathrm{R}
\end{aligned}
$$

Keterangan :

$\mathrm{R}=$ jari-jari bumi adalah $6371(\mathrm{~km})(1$ derajat $=0,0174532925$ radian $)$

$\Delta$ lat $=$ jumlah perubahan dalam garis lintang $(\mathrm{km})$

$\Delta$ long = besarnya perubahan dalam bujur $(\mathrm{km})$

$\mathrm{d}=\operatorname{jarak}(\mathrm{km})(10)$

\section{HASIL DAN PEMBAHASAN}

\subsection{Perancangan Data}

Berdasarkan analisis sistem berjalan yang dilakukan pada penelitian ini peneliti menganalisis terhadap kinerja sistem aplikasi dan efisiensi pencarian petshop yang masih menggunakan cara

\begin{tabular}{|c|c|c|}
\hline Aspek & Kendala & Solusi \\
\hline $\begin{array}{l}\text { Performance } \\
\text { (kinerja) }\end{array}$ & $\begin{array}{l}\text { Kinerja sistem yang masih manual } \\
\text { dimana pelanggan harus mencari } \\
\text { informasi petshop sangat sulit }\end{array}$ & $\begin{array}{l}\text { Menyediakan fitur untuk mencari } \\
\text { petshop terdekat }\end{array}$ \\
\hline $\begin{array}{l}\text { Information } \\
\text { (informasi) }\end{array}$ & $\begin{array}{l}\text { Informasi tentang data reservasi, } \\
\text { data produk sering terjadi } \\
\text { kekeliruan karena tersimpan di } \\
\text { arsip atau buku-buku. }\end{array}$ & $\begin{array}{lr}\text { Dibuatkan database sebagai } \\
\text { tempat penyimpanan data master } \\
\text { seperti data reservasi, data produk } \\
\text { sehingga } \\
\text { kekeliruan. }\end{array}$ \\
\hline $\begin{array}{l}\text { Economy } \\
\text { (ekonomis) }\end{array}$ & $\begin{array}{l}\text { Pemborosan biaya dalam ongkos } \\
\text { untuk perjalanan ke lokasi dan } \\
\text { Pencatatan data reservasi, dan } \\
\text { produk memerlukan biaya yang } \\
\text { cukup besar apabila sering terjadi } \\
\text { kesalahan, hal ini menyebabkan } \\
\text { pembengkakan biaya karena masih } \\
\text { bersifat arsip atau buku-buku. }\end{array}$ & $\begin{array}{l}\text { Menyediakan fitur pemilihan } \\
\text { lokasi dan dibuatkan form edit } \\
\text { untuk mengubah data jika terjadi } \\
\text { kesalahan atau perubahan pada } \\
\text { data tidak menimbulkan biaya } \\
\text { berlebih. }\end{array}$ \\
\hline $\begin{array}{l}\text { Control } \\
\text { (pengendalian) }\end{array}$ & $\begin{array}{l}\text { Tidak adanya proteksi terhadap } \\
\text { data reservasi dan data produk } \\
\text { karena semua data yang ada } \\
\text { disimpan dalam bentuk arsip atau }\end{array}$ & $\begin{array}{l}\text { Di sediakan fitur history diberikan } \\
\text { hak akses seperti validasi saat } \\
\text { login sehingga tidak sembarang } \\
\text { orang dapat melihat dan mengolah }\end{array}$ \\
\hline
\end{tabular}
manual dan lalu membandingkan dengan kinerja dari sistem yang akan dibuat menggunakan metode PIECES [14].

Tabel 1. Metode PIECES 


\begin{tabular}{|l|l|l|}
\hline & $\begin{array}{l}\text { buku-buku yang dapat dengan } \\
\text { mudah dibuka dan diolah oleh } \\
\text { setiap orang sehingga } \\
\text { menyebabkan kerusakan atau } \\
\text { kehilangan data. }\end{array}$ & $\begin{array}{l}\text { data serta terhindar dari kerusakan } \\
\text { maupun kehilangan data. }\end{array}$ \\
\hline $\begin{array}{l}\text { Efficiency } \\
\text { (efisiensi) }\end{array}$ & $\begin{array}{l}\text { Informasi pemesanan yang dicatat } \\
\text { dengan form pemesanan tidak } \\
\text { direkap kembali melalui ms.word }\end{array}$ & $\begin{array}{l}\text { Menyediakan halaman data } \\
\text { pelanggan dan data reservasi } \\
\text { ketika melakukan pemesanan } \\
\text { tersimpan pada database }\end{array}$ \\
\hline $\begin{array}{l}\text { Services } \\
\text { (pelayanan) }\end{array}$ & $\begin{array}{l}\text { Proses reservasi pelanggan } \\
\text { membutuhkan waktu lama saat } \\
\text { petshop ramai yang menyebabkan } \\
\text { antrian pelanggan menjadi } \\
\text { panjang. }\end{array}$ & $\begin{array}{l}\text { Dibuatkan form reservasi yang } \\
\text { dapat digunakan diakses secara } \\
\text { online dan bersamaan sehingga } \\
\text { tidak menyebabkan antrian yang } \\
\text { panjang. }\end{array}$ \\
\hline
\end{tabular}

Sedangkan Metode digunakan untuk menghitung jarak antara titik di permukaan bumi menggunakan garis lintang (longitude) dan garis bujur (lattitude) sebagai variabel inputan. Haversine formula adalah persamaan penting pada navigasi, memberikan jarak lingkaran besar antara dua titik pada permukaan bola (bumi) berdasarkan bujur dan lintang. Dengan mengasumsikan bahwa bumi berbentuk bulat sempurna dengan jari-jari R 6.367, $45 \mathrm{~km}$, dan lokasi dari 2 titik di koordinant bola (lintang dan bujur) masing-masing adalah lon1, lat1, dan lon2, lat2, maka rumus Haversine dapat ditulis dengan persamaan sebagai berikut [15].

Rumus Haversine :

$$
\begin{aligned}
& \mathrm{x}=(\operatorname{lon} 2-\operatorname{lon} 1) * \cos ((\text { lat } 1+\mathrm{lat} 2) / 2) \\
& \mathrm{y}=(\operatorname{lat} 2-\operatorname{lat} 1) ; \\
& \mathrm{d}=\operatorname{sqrt}(\mathrm{x} * \mathrm{x}+\mathrm{y} * \mathrm{y}) * \mathrm{R}
\end{aligned}
$$

Contoh Perhitungan Haversine Formula

Lokasi 1: lon $1=119.800801$, lat $1=-0.790175$

Lokasi 2: lon2 $=119.8428$, lat2 $=-0.8989$

lat $1=-0.790175 * 0.0174532925$ radian $=-0.013791155$ radian

lon $1=119.800801 * 0.0174532925$ radian $=2.090918422$ radian

lat $2=-0.8989 * 0.0174532925$ radian $=-0.01569$ radian

lon $2=119.8428 * 0.0174532925$ radian $=2.091651$ radian

$\mathrm{x}=(\operatorname{lon} 2-\operatorname{lon} 1) * \cos (($ lat $1+$ lat 2$) / 2)$

$=(2.091651-2.090918422) * \cos ((-0.013791155+-0.01569) / 2)$

$=0.0007329412$

$\mathrm{y}=($ lat2-lat 1$)$

$=(-0.01569-(-0.013791155))$

$=-0.001897609$

$\mathrm{d}=\operatorname{sqrt}(\mathrm{x} * \mathrm{x}+\mathrm{y} * \mathrm{y}) * \mathrm{R}$ 
$=\operatorname{sqrt}((0.0007329412 * 0.0007329412)+(-0.001897609 *-0.001897609)) * 6371$

$=\operatorname{sqrt}(0.0000041381) * 6371$

$=12.96012927 \mathrm{~km}$

\subsection{Perancangan Proses}

Diagram Aktifitas merupakan alur aktifitas proses pencarian petshop terdekat. Gambar Diagram Aktifitas dapat dilihat di gambar 3.

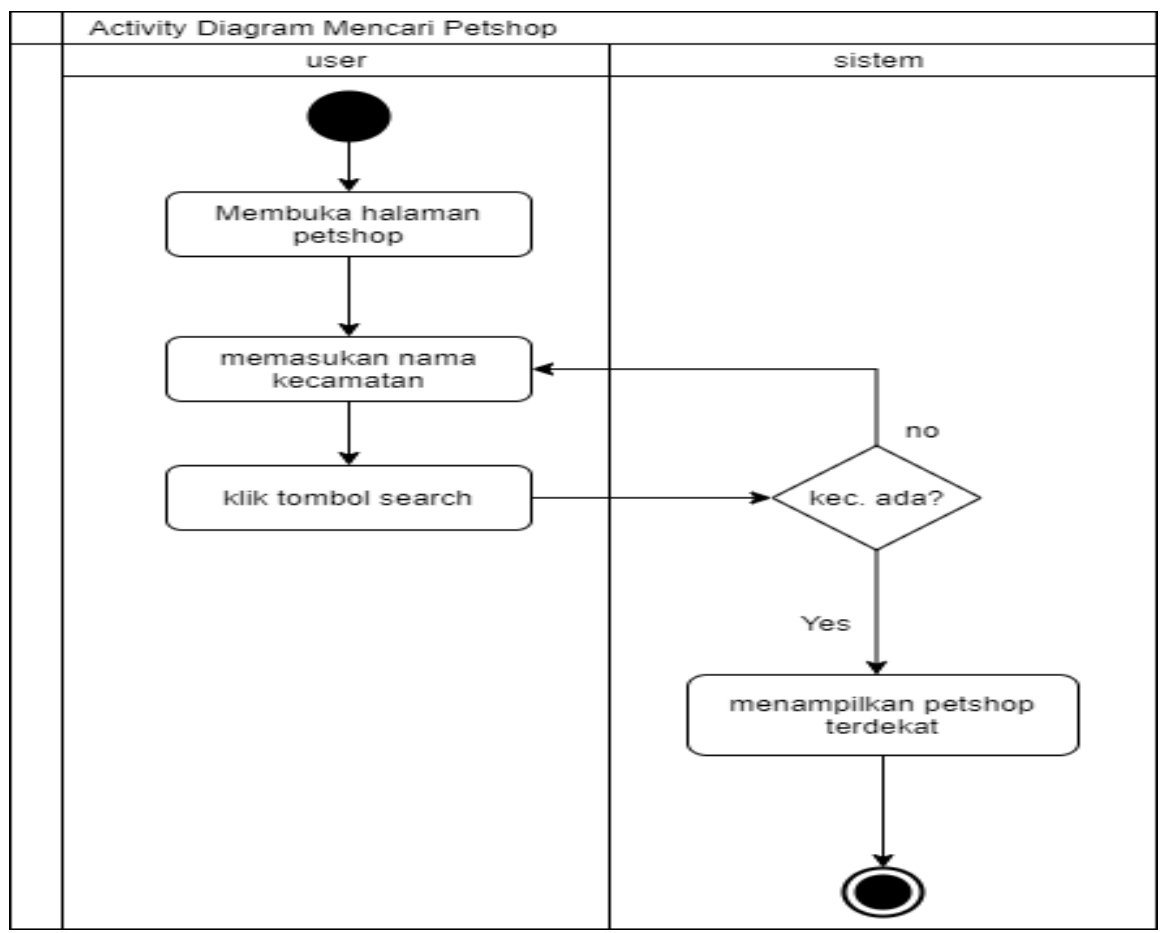

Gambar 3. Diagram Aktifitas Pencarian Petshop

\subsection{Perancangan Sistem}

Use case diagram yang diusulkan pada sistem web ini terdiri dari User dan Admin. Use case diagram menggambarkan relasi interaksi antar aktor dan sistem. Berikut adalah use case dari sistem dapat dilihat di gambar 4 [16] :

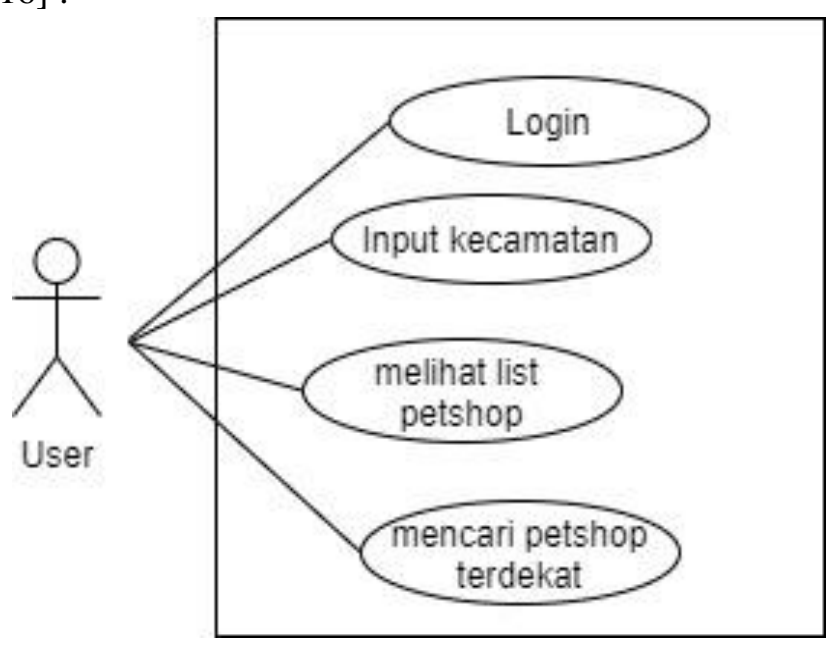

Gambar 4. Usecase User 


\subsection{Implementasi Sistem}

Pada gambar 4 menjelaskan rancangan halaman pencarian petshop. Gambar 4 ini berisi informasi-informasi lokasi petshop yang terdapat di daerah Jakarta Barat. user menginput kecamatan Jika data yang dimasukan sesuai maka sistem akan menampilkan petshop yang terdekat.

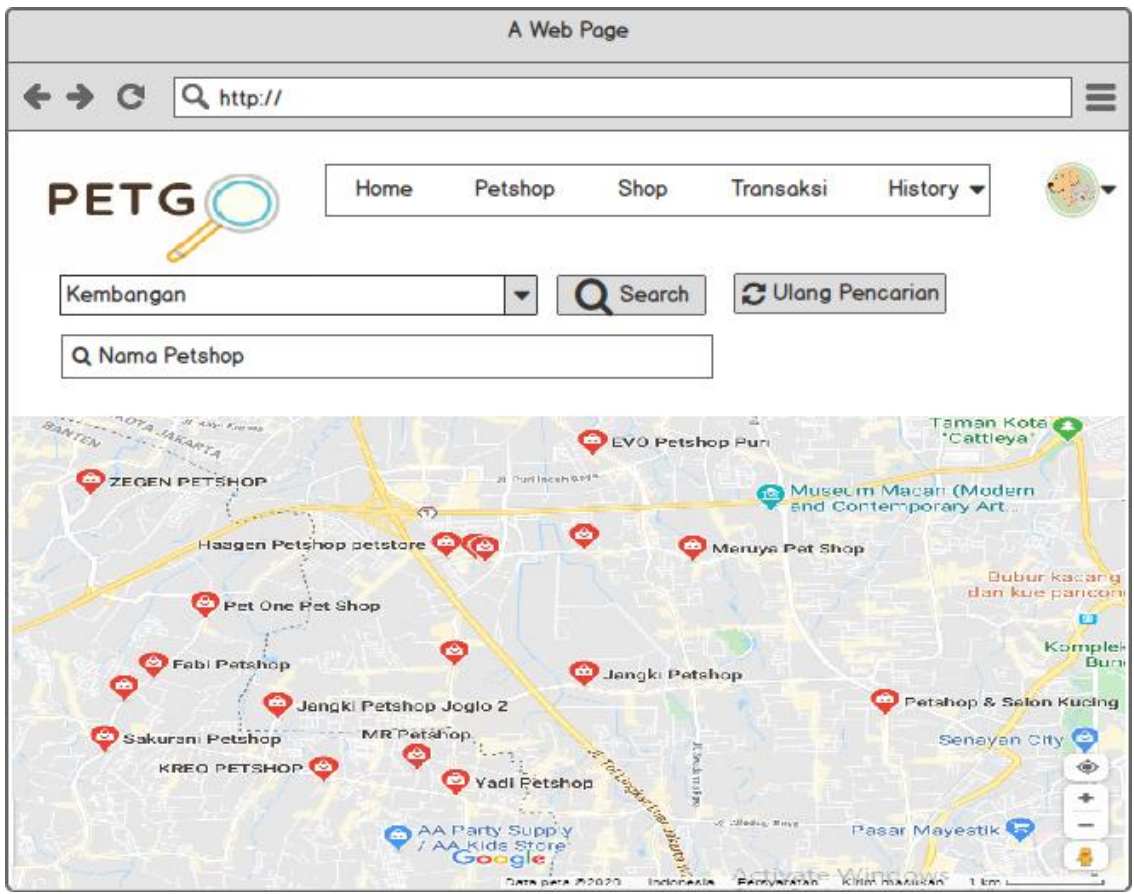

Gambar 5. Halaman Pencarian Petshop

Dengan menekan ikon jarak pada detail petshop maka akan menampilkan view Direction, yang menggambarkan petshop yang terdapat di daerah Jakarta Barat dapat dilihat di gambar 6 .

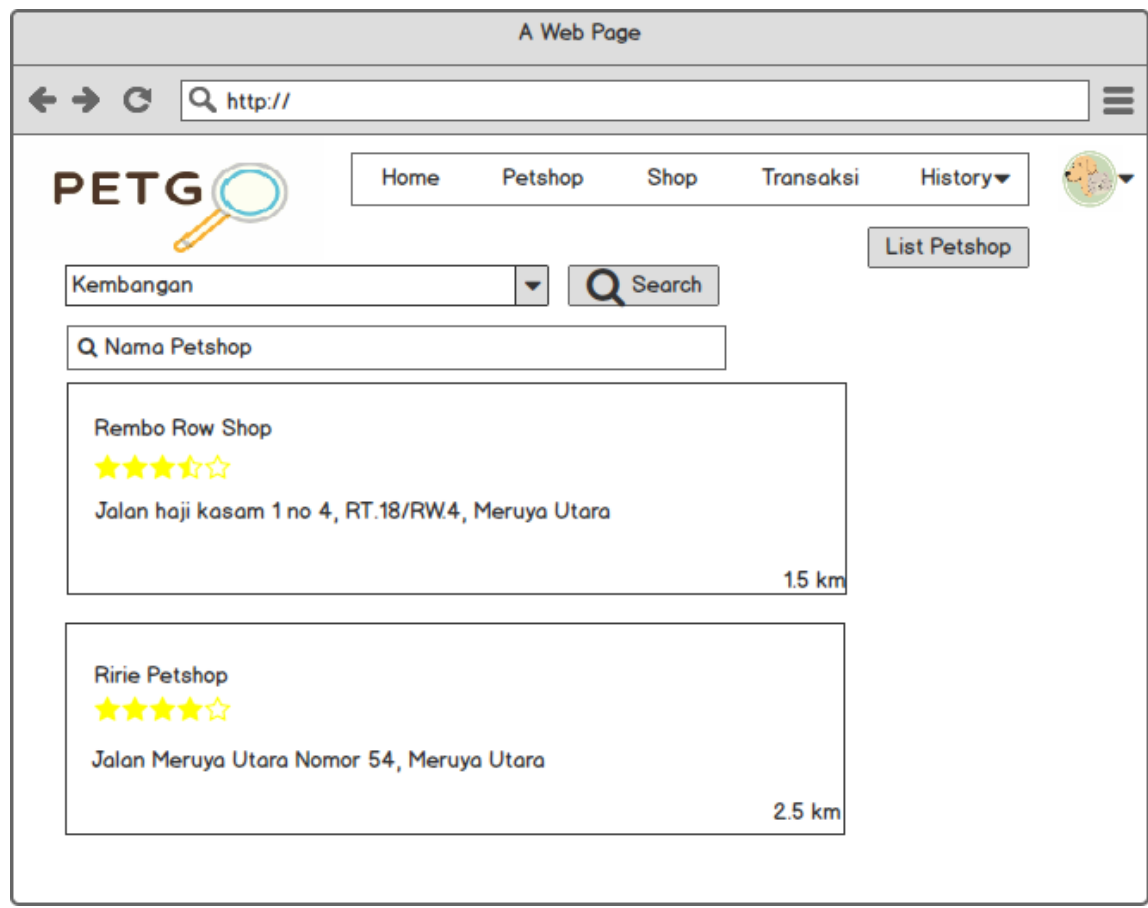

Gambar 6. Petshop Terdekat 
Dengan menekan tombol search sistem menampilkan koordinat tetap bagi pengguna sebelum menekan tombol Mencari Titik Lokasi yaitu koordinat untuk memandu pengguna menuju petshop yang dituju dapat dilihat di gambar 7 .

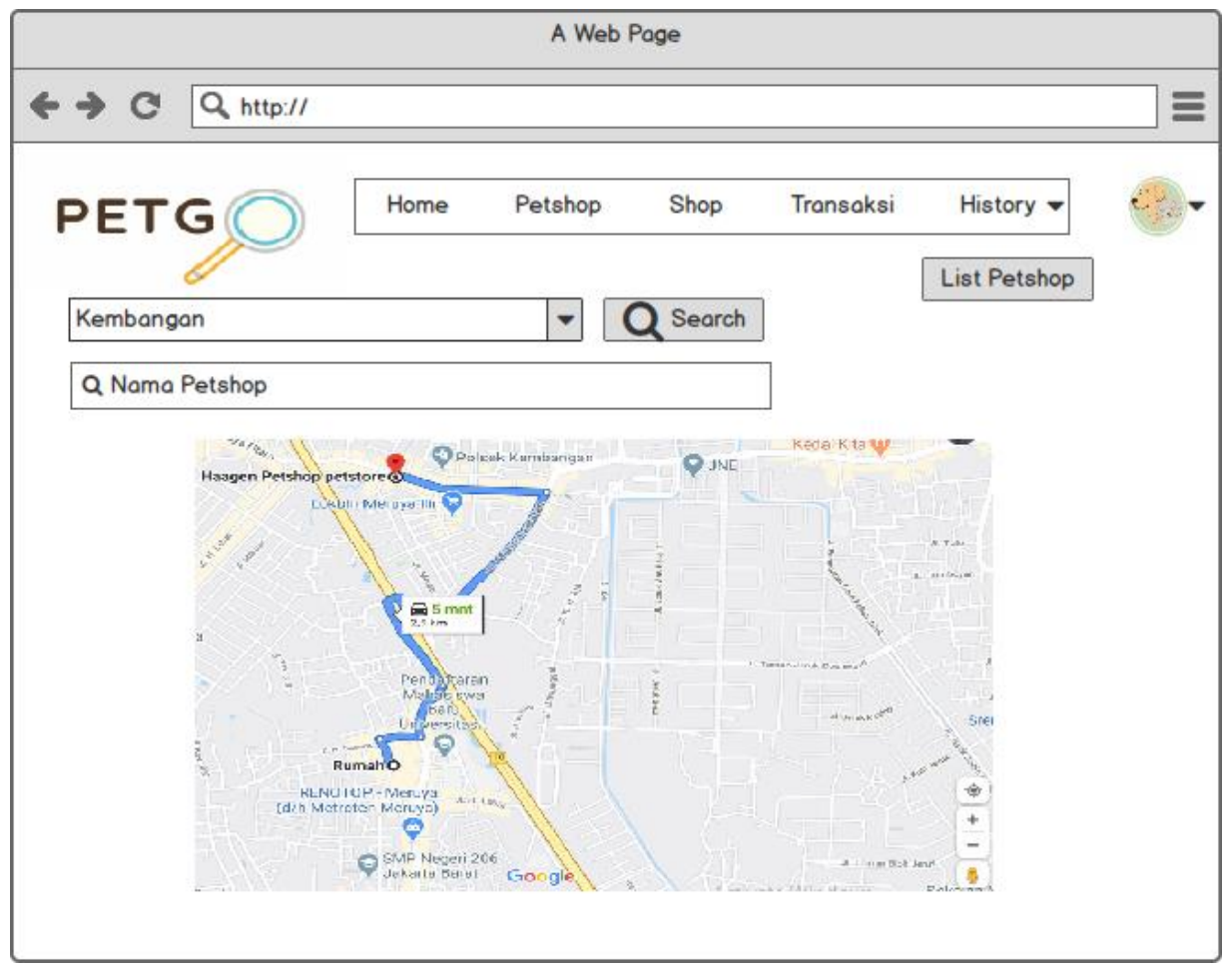

Gambar 7. View Direction

\section{KESIMPULAN DAN SARAN}

Berdasarkan penelitian yang telah dilakukan, maka kesimpulan yang didapat dari penelitian ini sebagai berikut :

1. Berhasil membuat usulan desain aplikasi website PetGo yang dapat memberikan informasi lokasi dan berbagai produk dan perawatan.

2. Berhasil merancang desain usulan perancangan sistem informasi pencarian lokasi wilayah Jakarta barat dapat dilakukan secara online.

3. Perancangan aplikasi ini dapat memberikan informasi yang detail untuk para pecinta hewan ini secara online.

4. Berhasil membuat usulan desain aplikasi PetGo yang dapat melakukan reservasi online dengan mudah dan melakukan penjualan produk-produk melalui website.

Berdasarkan dari kesimpulan diatas maka saran dari penulis supaya dapat mengembangkan usulan ini menjadi sebuah sistem aplikasi, sehingga dapat di implementasikan dan menambahkan fitur-fitur agar aplikasi lebih sempurna.

\section{UCAPAN TERIMAKASIH}

Penulis mengucapkan terima kasih kepada Instansi/perusahaan/lembaga yang telah memberi dukungan yang membantu pelaksanaan penelitian dan atau penulisan artikel. 


\section{DAFTAR PUSTAKA}

[1] U. Rahmiati, D and S. Pribadi, E, "Tingkat Pendidikan dan Status Ekonomi Pemilik Hewan Kesayangan dalam Hal Pengetahuan dan Penerapan Kesejahteraan Hewan," J. Vet. Sept. 2014, vol. 15, no. 3, pp. 386-394, 2014.

[2] R. Adiputra, K. I. Satoto, and R. Kridalukmana, "Rancang Bangun Aplikasi Layanan Perawatan dan Penitipan Hewan Berbasis SMS Gateway pada Toko Petshop PetZone," $J$. Teknol. dan Sist. Komput., vol. 2, no. 1, pp. 110-118, 2014.

[3] A. A. G. Ekayana and I. G. N. Eka Putra, "Rancang Bangun Sistem Pemberian Makan Dan Minum Hewan Peliharaan Berbasis Sms Gateway," S@Cies, vol. 6, no. 2. pp. 104-112, 2018.

[4] E. Prahasta, Sistem Informasi Geografis Konsep-Konsep Dasar (Perspektif Geodesi dan Geomatika). Bandung, 2009.

[5] E. Budiyanto, Sistem Informasi Geografis Menggunakan Arcview GIS. Yogyakarta: Andi Offset, 2005.

[6] Farid and Y. Yunus, "Analisa Algoritma Haversine Formula Untuk Pencarian," Ilk. J. Ilm., vol. 9, pp. 353-355, 2017.

[7] Harri Singgih Pratikto, Suraya, and E. Sutanta, "Sistem Pencarian Dan Pemesanan Rumah Kos Menggunakan Sistem Informasi Geografi (Sig),” J. Scr., vol. 1, no. 2, pp. 110-119, 2014.

[8] Roger S. Pressman, "Rekayasa Perangkat Lunak Pendekatan Praktis Buku Satu," no. Yogyarkata: Andi, 2015.

[9] I. Fatansyah, Basis Data. Bandung: Informatika, 1999.

[10] T. Luthfianto, P. Studi, T. Elektro, F. Teknik, and U. M. Purwokerto, "Menggunakan Metode Algoritma Menggunakan Metode Algoritma," vol. VIII, no. 2, 2017.

[11] A. Fauzi, F. Pernando, and M. Raharjo, "Penerapan Metode Haversine Formula Pada Aplikasi Pencarian Lokasi Tempat Tambal Ban Kendaraan Bermotor Berbasis Mobile Android," J. Tek. Komput., vol. 4, no. 2, pp. 56-63, 2018.

[12] Kusniyati Harni and H. Fadhillah, "Aplikasi Pencarian Ustadz Untuk Wilayah Dki Jakarta Menggunakan Algoritma Haversine Formula Berbasis Android," Petir, vol. 9, no. 2, pp. 102 $111,2019$.

[13] P. Dauni, M. D. Firdaus, R. Asfariani, M. I. N. Saputra, A. A. Hidayat, and W. B. Zulfikar, "Implementation of Haversine formula for school location tracking," J. Phys. Conf. Ser., vol. 1402, no. 7, 2019.

[14] J. E. K. Kendall, K.E., Analisis dan Perancangan Sistem, 5th ed. PT. Prenhallindo, Jakarta., 2003.

[15] D. Prasetyo and K. Hastuti, "Penerapan Haversine Formula Pada Aplikasi Pencarian Lokasi Dan Informasi Gereja Kristen Di Semarang Berbasis Mobile," Skripsi Tek. Inform. Univ. Dian Nuswantoro, 2015.

[16] B. H. W. T. Alan Dennis, System Analys and Design with UML 2.0 4th Edition. 2012. 